ks. Janusz Drewniak

\title{
Biblijne i liturgiczne wątki w twórczości Krzysztofa Pendereckiego
}

Tematyka religijna jest niewyczerpanym źródłem inspiracji artystycznej. Świadczy o tym niezwykle bogata twórczość z zakresu sztuk pięknych - malarstwa, literatury i muzyki. W twórczości kompozytorskiej czynnik religijny obecny jest w dwóch wymiarach - w warstwie tekstowej i muzycznej. Kompozytorzy minionych epok posługiwali się tekstem biblijnym lub liturgicznym. U twórców XX i XXI wieku spotykamy często także religijne utwory poetyckie oraz parafrazy i kompilacje tekstów biblijnych i liturgicznych. Z ksiąg Starego Testamentu kompozytorzy czerpią głównie łacińskie i polskie teksty psalmów, natomiast z Nowego Testamentu - fragmenty Ewangelii, jak opisy Męki Pańskiej oraz maryjny hymn Magnificat. Z kręgu formuł liturgicznych najczęściej wykorzystywane są teksty mszalne (Ordinarium i Proprium Missae; msza żałobna Requiem), litanijne, brewiarzowe (Jutrznia i Nieszpory) oraz hymny (np. Te Deum) i sekwencje (Stabat Mater). O religijnym wymiarze dzieła muzycznego stanowi także czynnik melodyczny. Źródłem opracowania kompozytorskiego mogą być melodie zaczerpnięte z chorału gregoriańskiego (antyfony, sekwencje, psalmy, wersety allelujatyczne) lub melodie pieśni kościelnych.

Utwory religijne można sklasyfikować ze względu na ich przeznaczenie. Religijny charakter wykazują rozbudowane pod względem formy i aparatu wykonawczego dzieła koncertowe niemające bezpośrednio zastosowania w liturgii (funkcja pozaliturgiczna), ale inspirowane tematyką sakralną. Pod pojęciem twórczości liturgicznej rozumie się kompozycje związane ściśle z liturgią Kościoła katolickiego i przeznaczone dla liturgii, a więc mające charakter użytkowy. Dorobek twórczy kompozytorów XX wieku zdominowała koncertowa muzyka religijna ${ }^{1}$.

${ }^{1}$ Por. St. DĄвEK, Kategorie badawcze i poznawcze w procesie analizy twórczości religijnej kompozytorów polskich XX wieku, w: Współczesna polska religijna kultura muzyczna jako przedmiot badań muzykologii. Zakres pojęciowy, możliwości badawcze. Materiały z sympozjum zorganizowanego przez Instytut Muzykologii Katolickiego Uniwersytetu Lubelskiego 16-17 lutego 1989 r., pod red. ks. B. Bartkowskiego, St. Dąbka, A. Zoły, Lublin 1992, s. 53. 
Krzysztof Penderecki (ur. 1933) należy do grona najwybitniejszych współczesnych kompozytorów. W jego dorobku znajdują się cztery opery, kilkanaście monumentalnych dzieł wokalno-instrumentalnych, ponad dwadzieścia utworów na zespół orkiestrowy, kilkanaście na instrument solowy i orkiestrę, utwory kameralne oraz na instrumenty solo. Ważną i pokaźną część twórczości stanowią kantatowo-oratoryjne dzieła o charakterze religijnym. Twórczość Pendereckiego nie ma bezpośredniego związku z liturgią. O jej koncertowym, pozaliturgicznym charakterze świadczy rozbudowana forma wykluczająca możliwość włączenia w struktury liturgii, również język muzyczny i środki kompozytorskie wykraczają poza krąg stylistyczny muzyki liturgicznej. Chociaż inspiracje artysty związane są ze sferą sacrum, przyświeca mu inny niż liturgiczny cel aktu twórczego.

W przypadku Pendereckiego impulsem do powstania dzieł sakralnych stała się budząca głębokie refleksje kompozytora lektura tekstów Starego i Nowego Testamentu (m. in. Psalmy Dawida, Stabat Mater, Pasja wg św. Łukasza, Jutrznia, Magnificat, Te Deum, Polskie Requiem). Bogaty dorobek wokalno-instrumentalny uzupełniają dzieła zbliżone tematycznie do problematyki religijnej podejmujące zagadnienia natury filozoficzno-moralnej (Czarna maska, Diably z Loudun, Dies irae, Kosmogonia, Strofy).

W kantatowo-oratoryjnej twórczości Krzysztofa Pendereckiego nawiązującej do sfery sacrum wyróżnia się trzy grupy utworów. Pierwszą stanowią kompozycje wykorzystujące teksty biblijne i liturgiczne (krąg liturgii łacińskiej: Pasja według św. Łukasza, Magnificat, Te Deum, Polskie Requiem, Siedem Bram Jerozolimy, Credo; krąg liturgii prawosławnej: Jutrznia, Pieśń Cherubinów, Hymn do św. Daniiła). Do drugiej grupy zalicza się utwory oparte na literackich interpretacjach tematów religijnych (Raj utracony). Trzecia grupa zawiera utwory niepodejmujące wprost tematyki religijnej i niezwiązane z obrzędami liturgicznymi, jednak ich treść i przesłanie odnosi się do sfery sacrum (Diabły z Loudun) ${ }^{2}$.

W utworach religijnych kompozytor preferuje język łaciński. W nim cytuje fragmenty Biblii (m.in. Canticum canticorum Salomonis, Pasja według św. Łukasza, Siedem bram Jerozolimy), teksty liturgii mszalnej (Credo, Polskie Requiem), hymny (Hymn do św. Wojciecha, Magnificat, Te Deum, Veni Creator), antyfony chorałowe (Benedicamus Domino), sekwencje gregoriańskie (Stabat Mater). Nieprzypadkowo upodobał sobie także starocerkiewne hymny oraz teksty liturgiczne (Hymn do św. Daniiła, Jutrznia, Pieśń Cherubinów). Jest to jego ukłon w kierunku chrześcijaństwa Wschodu oraz podkreślenie szacunku wobec religii prawosławnej. Język polski pojawia

${ }^{2}$ Por. R. ChŁopicka, Krzysztof Penderecki między sacrum a profanum. Studia nad twórczościa wokalno-instrumentalną, Kraków 2000, s. 14-15. 
się sporadycznie. Słowa rodzimych pieśni religijnych traktowane są jako interpolacje w tekstach łacińskich utworów sakralnych. Ojczystą poezję (K. I. Gałczyński, K. Przerwa-Tetmajer, L. Staff) Penderecki wykorzystywał w młodzieńczych pieśniach, natomiast w późniejszej twórczości jedynie w Psalmach Dawida posłużył się staropolskim tłumaczeniem psalmów.

Osobiste komentarze Pendereckiego do własnych dzieł religijnych, a także analiza jego kompozycji pozwalają stwierdzić, że najsilniejszym impulsem do powstania tej części twórczości jest afirmacja wiary³. Kompozytor wywodzi się z katolickiej rodziny, wychowywany był więc w duchu chrześcijańskim. Muzyka religijna, śpiew pieśni kościelnych, modlitwa oraz kultywowanie tradycji współtworzyły atmosferę religijności jego rodzinnego domu. Można pokusić się o stwierdzenie, że bez głęboko zakorzenionego w sercu ducha chrześcijańskiej pobożności nie mogłoby być mowy o stworzeniu tak bogatego dorobku kompozytorskiego o charakterze sakralnym. U źródeł aktu twórczego Krzysztofa Pendereckiego znajduje się więc doświadczenie wiary i jego religijne przeżycia duchowe ${ }^{4}$. Kompozytor ujawnił to w czasie konferencji prasowej poprzedzającej prawykonanie w 1966 roku w Münster jednego z największych jego dzieł - Pasji według św. Łukasza: „Jestem katolikiem (...) Nie mam nic przeciwko temu, aby moją muzykę traktowano jako "wyznanie"”s. Dobór źródeł tekstów (obok języka polskiego i łacińskiego także starocerkiewny), melodii i form utworów dowodzi, że artysta akcentuje ekumeniczny wymiar chrześcijaństwa. Wyraźnym ideowym przesłaniem jego twórczości jest chrześcijańska miłość bliźniego stanowiąca źródło szacunku wobec każdego człowieka bez względu na jego poglądy i wyznawaną wiarę. Kompozytor przyznaje, że wartości chrześcijańskie są natchnieniem dla jego dzieł kantatowo-oratoryjnych. „Moja sztuka, wyrastając z korzeni głęboko chrześcijańskich, dąży do odbudowania metafizycznej przestrzeni człowieka strzaskanej przez kataklizmy XX wieku. Przywrócenie wymiaru sakralnego rzeczywistości jest jedynym sposobem uratowania człowieka"6.

Wartościom chrześcijańskim Penderecki przypisuje ważną rolę kulturotwórczą w szeroko zakrojonej działalności człowieka. „Cywilizacja europejska wraz z jej kulturą i sztuką nierozerwalnie związana jest z chrześcijaństwem.

${ }^{3}$ Problem twórczego impulsu w dziedzinie kompozycji przedstawia ST. DĄBEK w artykule Wspótczesna muzyka religijna w refleksji metodologicznej, w: Ratio musicae, red. tegoż, Warszawa 2003, s. 107-112.

${ }^{4}$ Por. K. Lisicki, Szkice o Krzysztofie Pendereckim, Warszawa 1973, s. 115.

${ }^{5}$ K. Penderecki w wywiadzie z okazji prawykonania Pasji w Münster, 30 III 1966; cyt. za L. ERhardt, Spotkania z Krzysztofem Pendereckim, Kraków 1975, s. 89.

${ }^{6}$ K. Penderecki, Labirynt czasu. Pięć wykładów na koniec wieku, Warszawa 1997, s. 68. 
Ono to przez setki lat kształtowało jej oblicze i wszelkie jej osobliwości. Nie tylko filozofia, sztuki piękne, budownictwo, rodzina były zorganizowane według chrześcijańskich norm. (...) Wszelkie ludzkie tęsknoty, aspiracje i najsprzeczniejsze interesy wyrażały się w chrześcijańskich symbolach"7.

Główną fascynacją kompozytora w sferze sacrum jest problematyka ludzkiej egzystencji kreślona już od pierwszych kart Pisma Świętego. W wyborze biblijnej tematyki utworów wyraźnie widoczny jest prymat Starego Testamentu. Treści nowotestamentowe kompozytor odczytuje w duchu Pięcioksięgu. Naprzeciw wszechmocnego, potężnego, budzącego grozę Boga staje zanoszący błagania, żalący się, często także buntujący się człowiek. Przedchrześcijańska wizja Boga wyraźnie różni się od nowotestamentowego oblicza miłosiernego i kochającego Ojca ${ }^{8}$. Naczelna idea przenikająca znaczną część twórczości Pendereckiego wiąże się z poszukiwaniem przyczyn zła i nieszczęść, a także wizją nieuniknionego końca świata oraz związanego z nim sądu ostatecznego. Grzeszne pragnienie pierwszych ludzi dorównania Bogu kompozytor przenosi na wszystkie pokolenia. Nawiązując do zgubnych dla ludzkości XIX-wiecznych teorii filozoficznych F. Nietzschego i K. Marksa, Penderecki przestrzega przed ciągle aktualną szatańską pokusą: „Próba odejścia od Boga, a zwłaszcza zuchwała wola dorównania Mu, kończy się straszliwym i żałosnym upad-

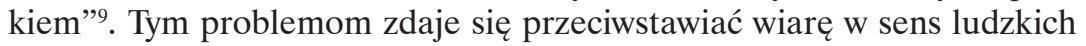
wysiłków zmierzających do naprawy świata i ostateczne zwycięstwo dobra nad złem oraz nadzieję nieśmiertelności, której fundamentem jest zmartwychwstanie Chrystusa. Przenika go jednak świadomość ograniczonych możliwości ludzkich. Pierwszoplanową i nieocenioną rolę przypisuje w tych staraniach Bogu oraz wartościom, które przyniosła światu religia chrześcijańska. „Człowiek nie da sobie rady bez interwencji Boga (...) Chrześcijaństwo powstrzymuje człowieka przed najniebezpieczniejszym dla niego, a od niepamiętnych czasów najbardziej kuszącym go występkiem, jakim jest hybris - grzech pychy i samoubóstwienia. Chrześcijaństwo powściąga, hamuje ową tęsknotę za uzurpatorskim przyznaniem sobie atrybutów boskich i w tym tkwi, jak sądzę, jego najgłębsza mądrość"10.

Chronologicznie najwcześniejszym dziełem inspirowanym tematyką religijną są Psalmy Dawida na chór mieszany, instrumenty strunowe i perkusję (1958). Warstwę tekstową tworzą fragmenty czterech psalmów (XXVIII , XXX, XLIII i CXLIII) zaczerpniętych z Psałterza w przekładzie

\footnotetext{
${ }^{7}$ K. Penderecki, Kulturotwórcza moc chrześcijaństwa, „Tygodnik Powszechny” 1 (1988), s. 3.

${ }^{8}$ Por. M. Tomaszewski, Krzysztof Penderecki i jego muzyka. Cztery eseje, Kraków 1994, s. 21.

${ }^{9}$ K. Penderecki, Kulturotwórcza moc chrześcijaństwa, art. cyt., s. 3.

${ }^{10}$ Tamże.
} 
Jana Kochanowskiego. Psalmy Dawida stanowią osobisty dialog artysty z Bogiem. Wybrane przez Pendereckiego teksty psalmów odbierane są jako niezwykle intymne, odautorskie modlitewne wyznanie. Penderecki zawarł w swym dziele najbardziej istotne treści całego Psałterza wyznaczające etapy modlitwy człowieka - dziękczynny Psalm $X X X$ jest wyrazem wdzięczności za dotychczasową Bożą opiekę, Psalm XLIII zawiera prośbę o dalsze łaski, natomiast wysławiający wierność i wspaniałomyślność Boga Psalm CXLIII jest prośbą o wysłuchanie i przychylność wobec ludzkości. Pochwalno-błagalny tekst pierwszego znaczącego dzieła Pendereckiego stanowi początek jego nieustannych poszukiwań związanych z tajemnicą ludzkiego istnienia i określa rozwinięty w późniejszych utworach artystyczny światopogląd oraz ideowe przesłanie kompozytora. Obok pragnienia wniknięcia w rzeczywistość transcendentnego istnienia Boga, kompozytora fascynuje świat przeciwstawny życiu, miłości, dobru, prawdzie i radości - rzeczywistość śmierci, nienawiści, zła, fałszu i cierpienia ${ }^{11}$.

Rozważania nad naturą człowieka, a szczególnie próba odpowiedzi na pytania dotyczące pochodzenia dobra i zła podjęta została w powstałej w latach 1976-1978 sacra rappresentazione Raj utracony. Kompozytor oparł swój utwór na dokonanym przez Christophera Fry'ego skrócie eposu J. Miltona, który na podstawie biblijnego opisu stworzenia, upadku pierwszych rodziców i odkupienia stworzył wizję dziejów ludzkości i wszechświata. Tematem dzieła Pendereckiego jest ukazanie dwóch przeciwstawnych światów - Boga i Szatana, będących uosobieniem dobra i zła, miłości i nienawiści. Pomiędzy niebiańską i piekielną sferą pojawia się, jako trzecia rzeczywistość, świat człowieka stworzonego na obraz i podobieństwo Boga, obdarzonego wolną wolą. Człowiek zmuszany jest do nieustannego podejmowania osobistych decyzji, wyboru pomiędzy przeciwstawnymi wartościami - Bóg proponuje mu szczęście u swojego boku, Szatan natomiast podsyca do ulegania zwodniczym pokusom. Wszystkie postaci sceniczne scharakteryzowane zostały przy pomocy specyficznych środków muzycznych. Każdemu z trzech światów kompozytor przyporządkował odrębne struktury dźwiękowe oparte na określonej hierarchii interwałów. Jednolite, czyste i doskonałe współbrzmienie symbolizuje postać Boga. Współtworzącym krąg niebiański aniołom przeznaczono harmonijny interwał. Wywołujący niepokój i napięcie dysonans towarzyszy momentom pojawienia się Szatana. Najbardziej zróżnicowany muzycznie jest zaś świat człowieka. Partia każdej postaci związana została z określonym rejestrem i barwą głosu. W muzycznej charakterystyce postaci scenicznych kompozytor wyróżnił Boga, dla którego przewidział generowaną przez elektroniczną aparaturę partię mówioną w języku hebrajskim,

${ }^{11}$ Por. M. Tomaszewski, Krzysztof Penderecki i jego muzyka, dz. cyt., s. 23-25. 
co szczególnie podkreśla transcendentny wymiar tej Osoby, a jednocześnie odróżnia od innych postaci. Pozostałym bohaterom: Adamowi, Ewie, aniołom, szatanom, grzechowi i śmierci przyporządkował głosy o zabarwieniu koloraturowym, lirycznym lub dramatycznym. Partie ludzi cechuje liryzm, melodyjność i harmonia. Rozdartą pomiędzy światem dobra i zła naturę człowieka symbolizują brzmienia dysonansowe. Partie Szatana charakteryzują się szerokim ambitusem i dużymi skokami interwałowymi. Można wnioskować, że „szatański akord”, któremu w dynamice forte wtóruje zespół instrumentów dętych blaszanych, symbolizuje zniszczenie pierwotnej harmonii świata stworzonego przez Boga. Również pozostałym pojawiającym się na scenie postaciom towarzyszą wybrane przez kompozytora instrumenty solowe lub grupy instrumentów ${ }^{12}$.

W sposobie przedstawienia bohaterów swego dzieła główną rolę Penderecki przypisuje konieczności ciągłych przeobrażeń i zmagań człowieka. Różnorodny i zmienny świat ludzkiej natury zajmuje w utworze największą przestrzeń dźwiękową. Centralnymi postaciami są Adam i Ewa. Bóg i Szatan stanowią ucieleśnienie wartości, między którymi człowiek wciąż dokonuje wyborów. Wyłaniająca się z dzieła Pendereckiego postać Chrystusa daleka jest od starotestamentalnych wyobrażeń potężnego Mesjasza. Zbawiciel jako cichy, pokorny Baranek oddaje swe życie w odkupieńczej ofierze za grzeszną ludzkość. Kompozytor akcentuje chrześcijański wymiar wielkości Boga i człowieka realizujący się w potędze miłości. Mimo upadku pierwszych rodziców i grzesznej natury całej ludzkości, ostateczne przesłanie, jakie niesie Raj utracony, wyraża się w nadziei powtórnego zjednoczenia z Bogiem. Radosną perspektywę harmonijnego współistnienia ludzkości ze Stwórcą kompozytor wyraża w finale dzieła, gdy w momencie opuszczenia Raju przez Adama i Ewę całą scenę przenika świetlisty blask z towarzyszącym tej scenerii czystym dźwiękiem orkiestry ${ }^{13}$.

Passio et Mors Domini nostri Jesu Christi secundum Lucam jest w twórczości Pendereckiego wydarzeniem niezwykłej miary, nie tylko ze względu na wartości artystyczne, ale również odautorskie przesłanie. Utwór powstał w 1965 roku i podejmuje temat męki oraz ukrzyżowania Chrystusa. Jego obsadę stanowi chór chłopięcy, trzy chóry mieszane, głosy solowe, recytator i wielka orkiestra symfoniczna wzbogacona organami. Zgodnie z koncepcją kompozytorską utwór przeznaczony został do wykonywania w kościele. W przebiegu struktur melodycznych oraz zagęszczeniu faktury chóralnej i orkiestrowej twórca uwzględnił warunki architektoniczne

${ }^{12}$ Por. R. ChŁopicka, Krzysztof Penderecki między sacrum a profanum, dz. cyt., s. 83-95.

${ }^{13}$ Por. tamże, s. 90. 
świątyni i związany z tym pogłos. Dzięki przestrzennemu rozmieszczeniu chórów osiągnięta została perspektywiczna głębia brzmienia ${ }^{14}$.

Penderecki mękę Chrystusa identyfikuje w Pasji z cierpieniem ludzkości spowodowanym okrucieństwem wojny. „Pasja jest cierpieniem i śmiercią Chrystusa, ale również cierpieniem i śmiercią Oświęcimia, tragicznym doświadczeniem ludzkości z połowy dwudziestego stulecia” ${ }^{15}$. „Sięgnąłem po archetyp pasji, by wypowiedzieć nie tylko mękę i śmierć Chrystusa, ale i okrucieństwo naszego wieku, męczeństwo Oświęcimia. Chodziło mi o to, aby widz poprzez napięcie i dramatyzm muzyki został włączony w sam środek wydarzeń. Jak w średniowiecznym misterium, gdzie nikt nie stał z boku. Każdy może być wciągnięty przez ów tłum pasyjny, turbę, który domaga się ukrzyżowania Chrystusa, podobnie jak każdego dotyczy odkupienie"16. Wizja cierpienia Chrystusa i człowieka XX wieku staje się częścią przesłania artysty, który każdy wymiar ludzkiej egzystencji wkomponowuje w sferę sacrum. Koncepcja utożsamienia odkupieńczej ofiary Chrystusa z tragedią człowieka przeżywającego gehennę II wojny światowej sprawia, że Pasja staje się tak bardzo polska, związana z tradycjami polskiego katolicyzmu. Polskość dzieła podkreśla wykonywany przez altówkę solo motyw intonowany na początku II części (passacaglia Popule meus oraz aria sopranowa Crux fidelis) oparty na melodii polskich suplikacji Święty Boże. Powstanie Pasji zbiegło się z obchodami Tysiąclecia Chrztu Polski (1966), w związku z czym utwór dedykowany został jako milenijna pamiątka kompozytora dla narodu.

Twórczym impulsem dla pomysłu skomponowania Pasji stał się zachwyt nad lekturą tekstu Ewangelii. Szczególnie opracowanie św. Łukasza od dawna fascynowało kompozytora walorami poetyckimi. Pragnąc spotęgować dramaturgię utworu, twórca sięgnął także po inne teksty. Wykorzystał nie tylko wybrane rozdziały Ewangelii według św. Łukasza (rozdział 22 i 23), ale i św. Jana (rozdział 19), które uzupełnił fragmentami wielkopostnych psalmów i lamentacji. „Zamierzeniem moim było odejście od relacji statycznej, od opowiadania wydarzeń ewangelicznych. Pasja w zamyśle jest dynamicznym, a niekiedy nawet drapieżnym przeżyciem"17. Dzieło rozpoczyna scena na Górze Oliwnej, kończy natomiast śmierć Jezusa na krzyżu. Pragnąc wiernie odtworzyć najistotniejsze wydarzenia Wielkiego Tygodnia, kompozytor „zapożycza” z Ewangelii św. Jana opis drogi krzyżowej i rozmowę Chrystusa z Matką, których nie relacjonuje św. Łukasz. Naturalna melodyka i muzyczna rytmika łacińskiego tekstu potęguje

\footnotetext{
${ }^{14}$ Por. K. Lisicki, Szkice o Krzysztofie Pendereckim, dz. cyt., s. 112-113.

${ }^{15}$ R. WAsita, Awangarda i dziedzictwo (wywiad), „Polska” 7 (1966), s. 5.

${ }^{16}$ K. Penderecki, Passio artis et vitae, „Dekada Literacka” 11/12 (1992), s. 4.

${ }^{17}$ R. WAsita, Awangarda i dziedzictwo, art. cyt., s. 5.
} 
dramaturgię utworu. Doskonała integracja słowa z warstwą muzyczną powoduje, że w Pasji można mówić nawet o nadrzędnej funkcji tekstu wobec muzyki ${ }^{18}$. W akcie percepcji utworu uaktywnia się większość zmysłów, przez co słuchacz zdaje się realnie uczestniczyć w opisywanych wydarzeniach Wielkiego Tygodnia. Przedstawiając ostatnie momenty życia Chrystusa, Penderecki sięga do wzoru J. S. Bacha i dzieli swoje dzieło na dwie części: Mękę i Śmierć. Dążąc do wytworzenia klimatu boleści i rozpaczy, jaki towarzyszył tragicznym wydarzeniom sprzed dwóch tysięcy lat, zaangażował ogromny aparat wykonawczy. Nowością Pasji Pendereckiego wobec wielkich dzieł tego gatunku powstałych w minionych wiekach jest zastąpienie recytatywów tekstem mówionym, dzięki czemu partia Ewangelisty nabiera większej wyrazistości i wyodrębnia się z całej akcji dramatycznej utworu.

Narodowy charakter ma także Polskie Requiem. Utwór powstawał w latach 1980-1984 (część Sanctus datowana jest na 1993 rok). Poszczególne części missa pro defunctis dedykowane zostały pamięci ofiar zbrodni katyńskiej, obozu koncentracyjnego w Oświęcimiu, Warszawskiego Getta, Powstania Warszawskiego, ponadto o. Maksymilianowi Kolbe oraz kard. Stefanowi Wyszyńskiemu. W dedykacjach kompozytor nawiązuje do współczesnej historii Polski. Dzieło komponowane w czasie stanu wojennego spełniało wymowną funkcję podtrzymania ducha w narodzie. W Polskim Requiem wykorzystane zostały teksty łacińskiej liturgii mszalnej za zmarłych oraz fragmenty Księgi Psalmów. W części lamentującego Recordare pojawia się jako temat passacaglii motyw suplikacji Święty Boże, który powoduje wyciszenie emocji i uspokojenie. Penderecki oparł swoje dzieło na tekstach mszy za zmarłych, dokonał jednak ich specyficznego doboru, bazując na poetyckich walorach oraz symbolicznym odniesieniu do sfer związanych z tematyką śmierci: światła utożsamianego z wiarą i nadzieją przebywania z Bogiem oraz ciemności wyrażającej towarzyszące wizji Sądu Ostatecznego uczucie grozy i rozpaczy ${ }^{19}$.

Polskie Requiem określić można jako oratorium dramatyczne wnikliwie podejmujące problem postawy człowieka wobec śmierci. Utwór jest kolejnym przykładem intelektualnego i artystycznego zaangażowania kompozytora w próbę odpowiedzi na pytania dotyczące sensu istnienia człowieka. Ważne miejsce w jego muzycznych rozważaniach zajmuje Stwórca - Pan życia i śmierci, jednak, co charakterystyczne dla zagłębiania się Pendereckiego w tematykę eschatologii, pierwszoplanowym bohaterem staje się człowiek rozdarty między zwątpieniem i nadzieją. Celem kompozytora jest ukazanie duchowej potęgi człowieka, który poddany okrucieństwu przemocy, w obliczu śmierci, zwracając się w modlitwie ku Bogu, w Nim

${ }^{18}$ Por. K. Lisicki, Szkice o Krzysztofie Pendereckim, dz. cyt., s. 100-111.

${ }^{19}$ Por. R. CHєорICKA, Krzysztof Penderecki między sacrum a profanum, dz. cyt., s. 101. 
odnajduje nadzieję na wyzwolenie od $\mathrm{zła}^{20}$. Penderecki zaszczepił Polskiemu Requiem ducha wspólnotowej modlitwy o charakterze dziękczynno-błagalnym, pochwalnym i medytacyjnym. Klimat modlitewnego skupienia osiąga, stosując zmienną obsadę partii wokalnej i kontrastujące środki muzyczne. Kompozytor w partii chóralnej posługuje się szeptem i mową, w bezpośrednim sąsiedztwie stosuje recytatyw i śpiew liryczny. Liczne repetycje istotnych w toku narracji nadają utworowi charakter liturgicznej celebracji missa pro defunctis. Nastrój wspólnotowej modlitewnej medytacji potęgują antyfonalnie opracowane chóry a cappella.

W 1969 roku Krzysztof Penderecki skomponował operę Diabły z Loudun, do której libretto opracował na podstawie dokonanej przez J. Whitinga teatralnej adaptacji dzieła A. Huxleya The Devils of Loudun. Akcja opery rozgrywa się w XVII wieku i dotyczy historycznego wydarzenia - procesu i spalenia na stosie w 1634 roku oskarżonego o praktyki satanistyczne księdza Urbana Grandiera. Głównym świadkiem procesu była przełożona urszulanek matka Joanna. Motywem przenikającym treść opery jest skomplikowany świat przeżyć głównych bohaterów dramatu i ich wewnętrzne przeobrażenia. Ksiądz Grandier przed spaleniem na stosie zdobywa się na szlachetny gest przebaczenia win fałszywym świadkom i swoim oprawcom. Jego tragiczny los stał się dla Pendereckiego okazją do przedstawienia śmierci jako symbolu moralnego zwycięstwa, ostatecznego tryumfu dobra i prawdy nad złem i kłamstwem. Mamy tu do czynienia z ciekawą interpretacją tragicznej historii człowieka nawiązującej do ostatnich chwil życia Chrystusa. Kaźń księdza Grandiera przypomina mękę Zbawiciela. Kompozytor w scenie cierpienia kapłana skazanego na tortury, jego pochodzie na miejsce stracenia, a także w geście przebaczenia dostrzega analogię do procesu, drogi krzyżowej i śmierci Pana Jezusa. Bezsilność wobec niesprawiedliwości oraz wyrok skazujący Grandiera na tortury i śmierć na podstawie fałszywego świadectwa przywołuje na myśl sąd nad Chrystusa; lęk przed śmiercią - modlitwę w Ogrodzie Oliwnym i zmaganie z własnym człowieczeństwem; szyderstwo i poniżanie Grandiera - zniewagi rzymskich żołnierzy; zdrada i „pocałunek pokoju” egzorcysty Ojca Barré - pocałunek i zdradę Judasza; droga na miejsce stracenia wśród pełnego nienawiści tłumu żądnego sensacji - drogę krzyżową Chrystusa; słowa przebaczenia oprawcom: „wybacz im, wybacz moim nieprzyjaciołom” - wyznanie Jezusa na krzyżu: „przebacz im, bo nie wiedzą co czynią”. Także osoba matki Joanny przywodzi na myśl tragiczną postać Judasza. Judasz w Ewangelii, podobnie jak Joanna w operze Pendereckiego, staje się narzędziem w ręku szatana i bezpośrednią przyczyną śmierci głównego bo-

\footnotetext{
${ }^{20}$ Por. tamże, s. 104.
} 
hatera. Zwycięstwo miłości nad nienawiścią wyrażające się w przebaczeniu nieprzyjaciołom staje się głównym przesłaniem utworu ${ }^{21}$.

Ważny dla Kościoła i Polski wybór na papieża Karola Wojtyły Krzysztof Penderecki uwiecznił w1980 roku, komponując Te Deum dedykowane polskiemu papieżowi. Istotny jest także inny kontekst historyczny powstania dzieła - ujrzało ono światło dzienne tuż przed przełomowymi dla Polski wydarzeniami sierpniowymi. Dziś możemy sądzić, że duchowa przemiana polskiego narodu nieprzypadkowo dokonała się kilkanaście miesięcy po pielgrzymce Jana Pawła II do Ojczyzny w 1979 roku. Bezpośrednim jednak motywem skomponowania dzieła było uwielbienie Boga za opatrznościowy dar papieża Polaka. Penderecki wielokrotnie podkreślał, jak wielką rolę w jego życiu osobistym i twórczym odegrał Ojciec Święty. „Żyję w świecie trzech wielkich Polaków, których osobowość, postawa, myśli i dzieła wywarły na mnie istotny wpływ i którym chciałbym w tym momencie wyrazić swoją wdzięczność. W pierwszej kolejności pragnę wymienić kapłana: Papieża Jana Pawła II, który z godną podziwu siłą i świeżością głosi ewangeliczne orędzie i dźwiga 'wszystkich, którzy upadają'"22.

Kompozytor w Te Deum posłużył się tekstem jednego z najstarszych łacińskich hymnów Kościoła katolickiego o charakterze pochwalnym, dziękczynnym i błagalnym i zachował jego trzyczęściową pod względem treści strukturę. Utwór zawiera pochwałę Trójcy Świętej, dziękczynienie wobec Chrystusa - Króla i Zbawiciela oraz błaganie o łaskawość Boga. Opatrznościowy wybór Polaka na Stolicę Piotrową stał się źródłem radości, którą w utworze akcentuje wykorzystany w centralnej części dzieła motyw religijno-patriotycznego hymnu Boże, coś Polskę.

Źródłem artystycznego natchnienia dla kolejnego dzieła oratoryjnokantatowego Krzysztofa Pendereckiego - Magnificat - stał się stanowiący kulminacyjny moment liturgii nieszporów brewiarzowych hymn uwielbienia Boga przez Maryję zaczerpnięty z Ewangelii według św. Łukasza (Łk 1, 3959). Dzieło przeznaczone zostało na głosy solowe, chór i orkiestrę. Zgodnie z tradycją liturgiczną, do biblijnego tekstu kantyku kompozytor dołączył małą doksologię. Utwór Pendereckiego jest muzyczną interpretacją idei zbawczych zawartych w ewangelicznym tekście hymnu maryjnego. Kompozytor dokonał jej przy pomocy właściwego sobie języka współczesnej ekspresji. Każdą z siedmiu części zróżnicował pod względem obsady, faktury, melodyki, harmoniki, dynamiki i agogiki. Mimo to cały utwór odznacza się wybitnie modlitewnym charakterem. Pierwszemu wersetowi kantyku kompozytor nadał ton osobistego wyznania Maryi kontemplującej wielkie dzieła

${ }^{21}$ Por. tamże, s. 43-52.

${ }^{22}$ K. Penderecki, Kulturotwórcza moc chrześcijaństwa, art. cyt., s. 3. 
Boga, które związał z jej osobą. W dalszych częściach przy pomocy niekonwencjonalnych środków wokalnych i instrumentalnych przybliża zbawcze wyzwanie, przed którym stanęła Maryja. Niektóre słowa-symbole wyrażające najistotniejsze idee zostają wyróżnione z całości tekstu przez wielokrotne powtórzenia w celu ich wyeksponowania (np. „magnificat” w części pierwszej, „misericordia” w części drugiej). W finale (doksologia) wykorzystana została kompletna obsada wykonawców, podczas gdy wcześniejsze odcinki przewidziane zostały dla zmniejszonego składu. W ostatniej, siódmej części po osiągnięciu kulminacji następuje stopniowa redukcja obsady i dynamiki. Czyste współbrzmienie zwielokrotnionej oktawy w końcowych taktach („Amen”) stwarza klimat wyciszenia i kontemplacji ${ }^{23}$.

Źródłem inspiracji religijnych Krzysztofa Pendereckiego jest nie tylko katolicka tradycja łacińska, z którą kompozytor się identyfikuje, lecz także wzorce z liturgii prawosławnej. Jutrznia (Utrenia) oparta została na najświętszych i najważniejszych w liturgii prawosławnej tekstach i melodiach pochodzących z obrzędów Wielkiego Tygodnia - Nieszporach Wielkiego Piątku opisujących pełną żalu ceremonię owinięcia całunem ciała Jezusa i Jego pogrzebu oraz radosnej Jutrzni Paschalnej odprawianej w nocy z Wielkiej Soboty na Niedzielę Zmartwychwstania. Części tego dyptyku noszą tytuły Złożenie Chrystusa do grobu (rok powstania 1970) oraz Zmartwychwstanie (1971). Tematycznie utwór stanowi kontynuację Pasji. Dokonana z wielkim wyczuciem i trafnością swobodna kompilacja tekstów nabożeństw świadczy o głębokim wniknięciu w tradycję Wschodu i rozumieniu liturgii prawosławnej. Penderecki podkreśla odmienność rzeczywistości transcendentnej od naturalnej, co stanowi istotny aspekt duchowości Wschodu. Kontrast między światem Boga i światem człowieka umiejętnie uwypukla przy pomocy środków muzycznych. Wprowadza jednak zmianę relacji zachodzących pomiędzy Stwórcą a stworzeniem: człowieka i rzeczywistość naturalną podnosi do rangi partnera prowadzącego dialog z Bogiem.

Istotnym czynnikiem, który wpłynął na powstanie Jutrzni, stała się jego fascynacja muzyką i językiem starocerkiewnym oraz korelacjami słownomuzycznymi liturgii prawosławnej. „Samo brzmienie starocerkiewnego języka wiąże się ściśle z muzyką tego utworu. Studiowałem starocerkiewny język i muzykę starocerkiewną, badałem stosunek tekstu do frazy muzycznej"24. Podziw i wielkie zainteresowanie kompozytora wzbudziła dźwiękowa, zewnętrzna forma obrządków wschodnich niewystępujących w liturgii katolickiej. Wnikliwe i twórcze przysłuchiwanie się autentycznym śpiewom cerkiewnym zaowocowało wyeksponowaniem głosów wokalnych przez

${ }^{23}$ Por. R. ChєоріскA, Krzysztof Penderecki między sacrum a profanum, dz. cyt., s. 71-75.

${ }^{24}$ B. Cybulski, Penderecki o sobie, diabłach i Dejmku (wywiad), „Teatr” 6 (1973). 
wprowadzenie partii chóralnych a cappella oraz częstym wykorzystaniem zespołu instrumentów dętych i perkusji. Zastosowane przez kompozytora środki muzyczne korespondują z emocjonalno-brzmieniowym klimatem prawosławnych obrzędów. Kulminacyjnym momentem nocnych ceremonii Jutrzni Paschalnej jest procesja wokół świątyni, w czasie której zbiorowym śpiewom i modlitwom towarzyszy wytwarzany przez wiernych ogłuszający dźwięk dzwonów, hałas kołatek i brzękadeł wyrażający ogromne poruszenie i radość ludu z powodu zmartwychwstania Chrystusa. Aktywne uczestnictwo tłumu wiernych w procesji stało się powodem wprowadzenia w drugiej części utworu dwóch chórów wzajemnie przekrzykujących się osób.

Ważne miejsce w religijnym dorobku Krzysztofa Pendereckiego zajmuje pochodzący z 1996 roku utwór Siedem bram Jerozolimy określany mianem VII Symfonii. Powód powstania tego monumentalnego dzieła przeznaczonego na pięciu solistów, recytatora, trzy chóry mieszane i orkiestrę kompozytor wyjaśnił w dedykacji: „Ad maiorem Dei gloriam et eius sanctis civitatis laudem aeternam”. Utwór uświetnił bowiem jubileusz 3000-lecia Jerozolimy (prawykonanie 9 stycznia 1997 roku), jest więc ukłonem w kierunku judaizmu. Warstwę tekstową stanowią fragmenty tekstów Starego Testamentu - Księgi Psalmów oraz proroctw Izajasza, Ezechiela, Jeremiasza i Daniela. Dzieło odwołuje się do bogactwa znaczeń liczb i terminów w Biblii oraz tradycji żydowskiej: „Utwór zatytułowałem Siedem bram Jerozolimy, nawiązując bardzo zresztą aluzyjnie do obciążonej bogatą symboliką topografii miasta (...) Utwór składa się z siedmiu części i żadna nie ma nazwy, nawet ta ostatnia - owa ‘siódma brama' przez którą symbolicznie ma przejść Mesjasz"25. Liczba siedem w języku biblijnym odczytywana jest jako święta i tajemnicza, pojawia się w historii zbawienia częstokroć, począwszy od siedmiodniowego dzieła stworzenia. Odnajdziemy ją także w Nowym Testamencie (Apokalipsa św. Jana). Penderecki posługuje się siódemką wielokrotnie: VII Symfonia, temat części II i IV zawiera siedem uderzeń, siedmiokrotnie powtórzony jest kończący dzieło trójdźwięk E-dur. Brama jest symbolem przejścia między dwoma stanami. Biblia odnosi znaczenie tego słowa do sfery ziemskiej i niebiańskiej. Kompozytor przyjmuje symboliczne znaczenie bramy stanowiącej granicę dwóch przeciwstawnych rzeczywistości - świata grzechu i świata doskonałości. Jerozolima w tradycji żydowskiej jest symbolem jedności i potęgi dwunastu pokoleń Izraela. Dla chrześcijan stanowi oczekiwaną z wiarą rzeczywistość Królestwa Bożego (Nowa Jerozolima), które nastanie na końcu czasów ${ }^{26}$.

${ }^{25}$ Passio artis et vitae (rozmowa A. i Z. Baranów z K. Pendereckim), [w:] K. Penderecki, Labirynt czasu. Pięć wykładów na koniec wieku, dz. cyt., s. 78.

${ }^{26}$ Por. R. CHÆорICKA, Krzysztof Penderecki między sacrum a profanum, dz. cyt., s. 109-110. 
Siedem bram Jerozolimy jest kompozycją wyrażającą zachwyt oraz pochwałę majestatu i potęgi Boga. Gloryfikacja wszechmocnego i nieśmiertelnego Boga sięga apogeum w części finałowej, która rysuje również obraz przyjścia Mesjasza. Kompozytor, sięgając po teksty biblijne (np. Psalm 129) oraz stosując bogactwo środków ekspresji muzycznej, osiąga efekt niezwykłego skupienia towarzyszącego modlitwie błagalnej o Boże miłosierdzie (część III). Część V jest psalmem pochwalnym o radosnym charakterze (Psalm 147). Części II i IV przywołujące myśl o potędze Jahwe dane są ku przestrodze przed niewiernością świętego miasta Jeruzalem ${ }^{27}$.

Utworem inspirowanym łacińskim tekstem liturgii mszalnej jest pochodzące z 1998 roku Credo przeznaczone na kwintet solistów, chór dziecięcy, chór mieszany i orkiestrę. Pierwotnym zamysłem kompozytora było stworzenie pełnego cyklu mszalnego (szkice zaczęły powstawać w 1996 roku), jednak w trakcie pracy artysta postanowił skupić się wyłącznie na tekście Credo, wzbogacając go fragmentami hymnów i psalmów. Swój wybór ograniczający się tylko do tej części Ordinarium Missae Penderecki uzasadnia następująco: „Credo jest najważniejszym tekstem w całości mszy, bowiem znajduje tu odbicie każda z myśli zawartych w pozostałych jej częściach"28. Utwór jest kolejnym dziełem o wymiarze ekumenicznym. Kompozytor posłużył się tekstem nicejsko-konstantynopolskiego wyznania wiary przyjętego powszechnie przez Kościół Wschodu i Zachodu i włączonego do liturgii na soborze w Aix-la-Chapelle w 798 roku. O uniwersalnym charakterze dzieła świadczy dołączenie fragmentów tekstów pochodzących z liturgii łacińskiej Triduum Paschalnego (hymny Pange lingua i Salve festa dies, antyfona Crux fidelis, Improperia: Popule meus i fragment polskiej wersji tego utworu: Ludu, mój ludu oraz wezwanie Któryś za nas cierpiat rany) oraz tekstu zaczerpniętego z tradycji protestanckiej (psalm Aus tiefer Not). Bogate wykorzystanie różnorodności odcieni brzmieniowych dziecięcego chóru i orkiestry znakomicie ilustruje uczucia wyrażone w wybranych tekstach rozszerzających liturgiczną formułę Credo.

Ramy architektoniczne potężnego, wieloczęściowego utworu stanowi pełniące funkcję ekspozycji uroczyste wyznanie wiary Credo in unum Deum oraz finałowe Et vitam venturi saeculi, w którym kompozytor wykorzystuje temat główny, jak również radosny śpiew paschalny Haec dies i Alleluja. Pozostałe części odnoszą się do najważniejszych momentów historii zbawienia - tajemnicy wcielenia i zmartwychwstania. Centrum dzieła, ze względu na kulminację wyrazową, stanowi część Crucifixus. Kilkakrotnie powracające motywy antyfony Crux fidelis oraz łacińskiego wezwania

\footnotetext{
${ }^{27}$ Por. tamże, s. 111-115.

${ }^{28}$ Cyt. za R. ChŁopicka, Krzysztof Penderecki między sacrum a profanum, dz. cyt., s. 116.
} 
Popule meus, którym na tle śpiewnie prowadzonej partii instrumentalnej towarzyszą modlitewne dopowiedzenia w języku polskim, tworzą lirycznomedytacyjny lament nad ukrzyżowanym Chrystusem ${ }^{29}$.

Credo jest nie tylko wybitnym artystycznym dokonaniem Krzysztofa Pendereckiego. Jest również traktowane jako jego publiczne wyznanie wiary w Boga, w Jego miłość, wyrażającą się odkupieńczą ofiarą Chrystusa na krzyżu. Dzięki tym wartościom utwór stanowi płynące z głębi duszy artystyczne przesłanie kompozytora na koniec minionego wieku. Świadczy o tym stylistyka utworu oraz jego materiał dźwiękowy. Osobiste, emocjonalne i duchowe zaangażowanie kompozytora w akt twórczy podkreśla włączenie fragmentów polskich śpiewów religijnych, wśród których dojrzewała jego wiara i pobożność.

Krzysztof Penderecki, będąc muzykiem, kompozytorem i chrześcijaninem, kult Boga przeżywa w sposób niekonwencjonalny, niedostępny dla większości ludzi. Horyzonty jego duchowości poszerza bogaty dorobek twórczy o charakterze religijnym. Dzieła inspirowane sferą sacrum oraz podejmujące problemy religijno-moralne zajmują ważne, a nawet pierwszoplanowe miejsce w jego twórczości. Tę opinię podzielają nie tylko krytycy muzyczni i wielbiciele jego talentu, ale, co najistotniejsze dla naszych rozważań, jest to również osobiste przekonanie kompozytora. Twórczość religijna wypływa z potrzeby serca, jest naturalną emanacją jego wnętrza. Utwory sakralne stanowią uzewnętrznienie uczuć i osobistych, duchowych przeżyć kompozytora, są więc wyrazem i świadectwem jego wiary. W akcie twórczym artysta odsłania ducha swojej religijności, który przenika do jego kompozycji. Natchnione treści Pisma Świętego Nowego Testamentu kompozytor odczytuje w duchu Pięcioksięgu, przez co akcentuje bliskość chrześcijaństwa z religią Narodu Wybranego. Przedstawiając postać Boga, posługuje się środkami, które wyrażają Jego potęgę i transcendencję. Ukazuje starotestamentalny obraz Boga niedostępnego człowiekowi, wykraczającego poza możliwości jego poznania. Nie brak jednak także akcentów podkreślających dobroć i miłosierdzie Stwórcy. Wśród wartości ewangelicznych eksponowanych w dziełach Pendereckiego prymat wiedzie potrzeba miłości i wzajemnego poszanowania między ludźmi, szczególnie między wyznawcami różnych religii. Stąd z treści jego religijnych dzieł wyłania się ekumeniczny wizerunek chrześcijaństwa. Inspiracją dla kompozytora staje się bogactwo liturgii wszystkich wyznań chrześcijańskich oraz elementy tradycji judaistycznej.

Penderecki w poszukiwaniach sensu istnienia oraz zgłębianiu praw rządzących ludzkim losem zastanawia się nad źródłem zła i nieszczęść, które zdają się być nierozerwalnie związane z ludzką egzystencją. Nad tymi dociekaniami góruje jednak wiara w sens wysiłków zmierzających do

${ }^{29}$ Por. tamże, s. 115-119. 
naprawy świata i ostatecznego zwycięstwa dobra nad złem oraz nadzieja nieśmiertelności, której fundamentem jest zmartwychwstanie Chrystusa.

W 1987 roku w przemówieniu wygłoszonym podczas uroczystości nadania mu doktoratu honorowego Uniwersytetu im. Adama Mickiewicza w Poznaniu Krzysztof Penderecki zapewnił o osobistym zaangażowaniu w pracy nad tworzeniem utworów sięgających do sfery sacrum. Wyraził jednocześnie pragnienie kontynuowania poszukiwań artystycznego wyrazu dla bogactwa tradycji chrześcijańskiej, które zapoczątkowane przed laty zaowocowały znakomitymi dziełami religijnymi: „Mój dorobek kompozytorski znaczony jest takimi, między innymi, utworami, jak Pasja wedtug św. Łukasza, Jutrznia, Kosmogonia, Raj utracony, których tytuły mówią same za siebie. Tej drodze pragnę pozostać wierny, te wartości pragnę dalej rozwijać”30.

Wtocławek

KS. JANUSZ DREWNIAK

\section{Summary}

Biblical and liturgical themes in Krzysztof Penderecki's activity

Krzysztof Penderecki (born 1933) is considered to be one of the most outstanding contemporary composers. The religious theme is often taken to be an inspiration for his vocal-instrumental output. Penderecki presents in his compositions the religious and moral problems related to the human nature and existence. The principal issues in his activity are a trial to find a reason of evil and misfortune and also the vision of ordeal. The composer makes use of not only biblical and liturgical texts but also religious poetry mainly in latin language. His religious output has a concert character thanks to the musician language and composing techniques. His own commentaries concerning his compositions prove that his religious activity is an artistic confession of his faith.

${ }^{30}$ K. Penderecki, Kulturotwórcza moc chrześcijaństwa, art. cyt., s. 3. 
